\title{
REORIENTASI KEBIJAKAN PEMIDANAAN BAGI PENYALAHGUNA NARKOTIKA
}

\author{
Setiyono \\ Fakultas Hukum Universitas Merdeka Malang \\ Jl. Terusan Raya Dieng No. 62-64 Malang \\ Setiyono60@yahoo.com
}

\begin{abstract}
Narcotics abuse is a felony offense which is punishable by criminal sanctions. A sentencing policy against narcotics abusers regardless of the position of the abuser as an offender or victim may have a negative impact in the coaching process for the abuser itself. In this case, it is necessary to reorient the policy of sanctions against narcotics abusers based on the basic idea and purpose of sanctions for narcotics abusers. Such a policy is a demanding situation and condition that can uphold the dignity of the narcotics abuser in society. Therefore, the policy of criminal sanctions in the Narcotics Act needs are depenalization or to be changed intotreatment sanction. Depenalization of criminal sanctions against narcotics abusers can be done through the policy of narcotics abusers rehabilitation both medically and socially, so that they can escape from narcotic dependency and can resocialize with the community.
\end{abstract}

Keywords: Narcotics Misuse, Policy, Criminal Sanction.

\begin{abstract}
Abstrak
Penyalahgunaan narkotika merupakan tindak pidana kejahatan yang diancam dengan sanksi pidana. Kebijakan pemidanaan terhadap penyalahguna narkotika tanpa memperhatikan kedudukan penyalahguna sebagai pelaku atau korban dapat menimbulkan dampak negatif dalam proses pembinaan bagi penyalahguna itu sendiri. Sehubungan dengan hal ini, perlureorientasi kebijakan sanksi terhadap penyalahguna narkotika yang didasarkan pada ide dasar dan tujuan sanksi bagi penyalahguna narkotika. Kebijakan demikian merupakan tuntutan situasi dan kondisi yang dapat menjunjung tinggi harkat dan martabat penyalahguna narkotika dalam masyarakat. Oleh karena itu, kebijakan sanksi pidana dalam Undang-Undang narkotika itu perlu didepenalisasi atau dirubah menjadi sanksi tindakan. Depenalisasi sanksi pidana terhadap penyalahguna narkotika ini dapat dilakukan melalui kebijakan rehabilitasi penyalah guna narkotika baik secara medis maupun sosial, sehingga mereka dapat melepaskan diri dari ketergantungan narkotika dan dapat bersosialisasi kembali dengan masyarakat.
\end{abstract}

Kata Kunci: Kebijakan, Pemidanaan, Penyalahguna Narkotika.

Persoalan dekriminalisasi dan kriminalisasi merupakan suatu kebijakan legislasi yang penting dalam merespon perkembangan nilai-nilai suatu bangsa, yang sekaligus dapat mengidentifikasi pola dan bentuk-bentuk perkembangan kejahatan yang terjadi dalam masyarakat. Sehubungan dengan kebijakan legislasi, di samping dekriminalisasi dan kriminalisasi, dalam hukum pidana juga dikenal kon- 
sep atau pengertian penalisasi dan depenalisasi. Kriminalisasi dan dekriminalisasi serta penalisasi dan depenalisasi merupakan konsep-konsep dasar berpikir para legislator. Kriminalisasi merupakan proses menjadikannya suatu perbuatan yang semula perbuatan yang tidak diancam dengan pidana (bukan perbuatan jahat, bukan tindak pidana) menjadi perbuatan yang diancam dengan pidana (perbuatan jahat, tindak pidana). Sebaliknya dekriminalisasi adalah proses menjadikannya suatu perbuatan yang semula merupakan perbuatan yang diancam dengan pidana (perbuatan jahat, tindak pidana) menjadi perbuatan yang tidak diancam dengan pidana (bukan perbuatan jahat, bukan tindak pidana). Kriminalisasi dan dekriminalisasi merupakan proses, aktivitas pergulatan nilai-nilai yang dipertimbangkan oleh para legislator kita di DPR. Ketika para legislator itu (akan) menentukan suatu aturan hukum (kebijakan legislasi), tentu seharusnya mereka mempertimbangkan nilai-nilai apa yang ingin dilindungi oleh aturan hukum (pidana) itu. Demikian pula sebaliknya, ketika para legislator akan mendekriminalisasikan suatu perbuatan tentu mereka juga mempertimbangkan nilai-nilai yang telah dilindungi oleh hukum (pidana) tersebut, apakah memang nilai-nilai yang telah dilindungi oleh aturan hukum (pidana) tersebut sudah tidak diperlukan lagi dalam sistem hukum dan sistem sosial kita.

Selain konsep kriminalisasi dan dekriminalisasi, dalam hukum pidana dikenal juga konsep atau pengertian penalisasi dan depenalisasi. Penalisasi merupakan proses kebijakan legislasi tentang sistem penjatuhan sanksi pidana. Apakah suatu perbuatan (jahat), tindak pidana itu perlu diancam dengan sanksi pidana atau tidak (sanksi non penal) merupakan hal penting dalam pertimbangannya. Jadi penalisasi itu merupakan wujud dari kebijakan legislasi yang mengancam pidana terhadap perbuatan pidana. Dengan demikian dalam suatu keadaan penalisasi dapat dikatakan sama dengan kriminalisasi, tetapi dalam keadaan lain penalisasi tidak sama dengan kriminalisasi, karena ada per- buatan-perbuatan yang dikriminalisasi tetapi tidak dipenalisasikan, melainkan dengan jenis sanksi yang lain yang bersifat non penal, yaitu dengan tindakan (maatregel). Sebaliknya, depenalisasi itu merupakan proses menghilangkan sanksi yang bersifat menghukum (pidana). Semula suatu perbuatan pidana atau tindak pidana tersebut diancam dengan sanksi pidana dirubah menjadi perbuatan pidana atau tindak pidana yang tidak diancam dengan sanksi pidana, melainkan diberi sanksi lain yang lebih bersifat edukatif dan humanis sehingga diharapkan pelaku tindak pidana tersebut bisa pulih kembali menjadi manusia yang baik dalam kehidupan masyarakat. Jadi dalam depenalisasi itu sifat perbuatan si pelaku tetap merupakan perbuatan yang bersifat melawan hukum, tetap merupakan perbuatan pidana, namun terhadap perbuatan pidana tersebut tidak dijatuhkan sanksi pidana, melainkan diberi sanksi tindakan atau sanksi lain yang bersifat mendidik.

Sesuai dengan topik "Reorientasi Kebijakan Pemidanaan bagi penyalahouna narkotika" ini, maka pisau analisis kebijakan pidana terhadap pengguna narkotika ini adalah tiga persoalan pokok hukum pidana, yaitu masalah tindak pidana, pertanggungjawaban pidana atau kesalahan atau persoalan mengenai orangnya dan masalah sanksi pidana atau tindakan. Berpijak dari pisau analisis tersebut, maka permasalahan yang perlu dikaji sehubungan dengan penyalahguna narkotika ini adalah pertama, apakah kualifikasi tindak pidana penyalahgunaan narkotika itu merupakan tindak pidana kejahatan atau tindak pidana pelanggaran? Kedua, untuk menentukan pertanggungjawaban pidana atau kesalahan, apakah status penyalahguna narkotika dalam sistem peradilan pidana itu merupakan pelaku tindak pidana atau korban tindak pidana atau pelaku tindak pidana sekaligus korban tindak pidana? Ketiga, apakah sanksi yang tepat bagi penyalahguna narkotika tersebut, sanksi pidana atau sanksi tindakan? Keempat, bagaimana kebijakan legislatif tentang penyalahguna narkotika dalam suatu Undang-undang? 


\section{Kejahatan atau Pelanggaran}

Rancangan KUHP yang akan datang pembedaan tindak pidana kejahatan dengan tindak pidana pelanggaran sudah tidak diperlukan lagi, namun sampai saat ini dalam hukum positif kita masih tetap berlaku dan juga dalam ilmu pengetahuan hukum pidana, pembedaan ini tetap penting dan perlu dipahami sebagai dasar penentuan suatu kebijakan, apakah tindak pidana penyalahgunaan narkotika itu berkualifikasi sebagai tindak pidana kejahatan atau tindak pidana pelanggaran? Secara historis, pembedaan kualifikasi tindak pidana tersebut sesuai dengan kebutuhan akan adanya suatu sistem yang lebih logis bagi kitab Undangundang hukum pidana yang didasarkan pada asasasas hukum tertentu, yang kemudian para ahli hukum pidana membuat pembagian perbuatan melawan hukum itu ke dalam dua macam "onrecht", yaitu "crimineel onrecht" dan "policie onrecht".

"Crimineel onrecht" merupakan perbuatan melawan hukum yang menurut sifatnya bertentangan dengan "rechtsorde" atau "tertib hukum" dalam arti yang lebih luas dari sekedar "kepentingan-kepentingan" sedangkan "policie onrecht" adalah setiap perbuatan melawan hukum yang menurut sifatnya bertentangan dengan "kepentingan-kepentingan yang terdapat di dalam masyarakat" (Van Hamel dalam P.A.F. Lamintang, 1990, 199). Seiring dengan perkembangannya, ilmu pengetahuan mencari secara intensif ukuran untuk membedakan kedua jenis tindak pidana ini. Menurut Sudarto $(1987,56,57)$, ada dua pendapat tentang perbedaan tersebut, yaitu perbedaan yang bersifat kwantitatif dengan perbedaan yang bersifat kwantitatif. Perbedaan yang bersifat kwantitatif hanya meletakkan kriteria yang dilihat dari segi kriminologi, yaitu pelanggaran itu lebih ringan dari pada kejahatan. Sedangkan perbedaan yang bersifat kwalitatif menentukan adanya 2 jenis tindak pidana yaitu" rechtsdelicten" dan "wetsdelicten". "Rechtsdelict" atau delik hukum adalah perbuatan yang bertentangan dengan hukum, bertentangan dengan rasa keadilan terlepas apakah perbuatan itu diancam dengan pidana dalam suatu undangundang atau tidak, jadi yang benar-benar dirasakan oleh masyarakat sebagai bertentangan dengan keadilan, misalnya pembunuhan, pencurian. Delikdelik semacam ini yang disebut kejahatan"(mala per se). Sedangkan "wetsdelict" atau delik undangundang adalah perbuatan yang oleh umum baru disadari sebagai suatu tindak pidana, karena undang-undang menyebutnya sebagai delik, jadi karena ada undang-undang mengancamnya dengan pidana, misal memparkir mobil di tempat yang ada tanda larangan parkir. Delik semacam ini yang disebut pelanggaran (mala quia prohibita) (Sudarto, 1987, 56, 57). Perbuatan tersebut ditentukan sebagai tindak pidana oleh undang-undang terlepas apakah perbuatan tersebut bertentangan dengan rasa keadilan, rasa kesusilaan masyarakat atau tidak. Jadi semata-mata karena undang-undang menentukan perbuatan tersebut sebagai tindak pidana.

Berdasarkan pengertian tindak pidana kejahatan dan tindak pidana pelanggaran tersebut, dapat ditentukan apakah tindak pidana penyalahgunaan narkotika itu merupakan tindak pidana kejahatan atau tindak pidana pelanggaran. Apabila tindak pidana penyalahgunaan narkotika merupakan kejahatan (recht delict) maka akan bertentangan dengan rasa keadilan dan kesusilaan masyarakat apabila tindak pidana penyalahgunaan narkotika itu didekriminalisasikan. Sebaliknya jika tindak pidana penyalahgunaan narkotika itu merupakan pelanggaran (wet delict) maka ada peluang yang besar untuk mendekriminalisasikan tindak pidana penyalahgunaan narkotika. Menurut hemat saya, tindak pidana penyalahgunaan narkotika merupakan kejahatan (recht delict) karena berdasarkan fakta, dampak penyalahgunaan narkotika dapat mengakibatkan orang yang menyalahgunakan narkotika tersebut terancam kesehatan fisik maupun psikisnya, bahkan sampai pada kematian. Laporan hasil survei tahun 2014 dapat diketahui 
lima keluhan utama yang banyak dialami responden, yaitu selera makan berkurang $(37 \%)$, rasa sesak napas di dada (31\%), rasa mual berlebihan $(26 \%)$, rasa lelah (fatique) berkepanjangan (26\%), dan rasa sakit di ulu hati (20\%)(Badan Narkotika Nasional, 2014, 25). Dari laporan akhir tahun 2014 tersebut juga diketahui bahwa berdasarkan pengakuan responden, jenis penyakit yang banyak diderita adalah HIV/AIDS (23\%), paru-paru (18\%), Hepatitis C (15\%). TBC (11\%), dan kejiwaan/ depresi (9\%)\%) (Badan Narkotika Nasional, 2014, 26).Dari laporan akhir tahun 2014 tersebut juga diketahui bahwa berdasarkan pengakuan dari $21 \%$ responden pernah mengalami kecelakaan lalu lintas akibat pengaruh dari penyalahgunaan narkotika dan obat-obatan terlarang\%) (Badan Narkotika Nasional, 2014, 27).

Bahkan secara sosiologis, dampak penyalahgunaan narkotika bisa mempengaruhi kehidupan masyarakat terutama para pemuda generasi bangsa. Menurut Slamet, seorang psikolog pada rehabilitasi pengguna Narkoba yang berada di Lido menyatakan bahwa dampak sosial yang dapat terjadi adalah bahwa pengguna Narkotika pada umumnya akan sangat merepotkan dan menjadi beban keluarga. Bahkan jika sampai tahap adiktif, seseorang yang sudah kecanduan narkotka tidak segan untuk menjual barang-barang yang ada di rumahnya sendiri hanya untuk membeli barang haram tersebut. Selain dampak di keluarga, Slamet mengungkapkan bahwa penggunaan Narkoba akan menimbulkan gangguan terhadap hubungan dan pergaulan sosial, bahkan dapat memicu suatu tindakan asosial dan antisosial maupun amoral. Tindakan-tindakan negatif tersebut akan berujung pada pengucilan oleh lingkungan (Slamet, 2015, 1).

Berdasarkan data dampak penyalahgunaan narkotika tersebut nampak bahwa penentuan kualifikasi perbuatan penyalahgunaan narkotika sebagai tindak pidana bukan semata-mata karena undang-undang melainkan karena memang dampak negatif penyalahgunaan narkotika tersebut bertentangan dengan rasa keadilan dan kesusilaan masyarakat. Hal ini sejalan dengan tujuan hukum pidana itu sendiri yaitu untuk melindungi kepentingan-kepentingan hukum dari setiap orang. Atas dasar hal ini, saya berpendapat bahwa penyalahgunaan narkotika adalah perbuatan jahat sehingga tetap sebagai perbuatan melawan hukum yang tidak perlu didekriminalisasi.

\section{Pelaku atau Korban Tindak Pidana}

Tindak pidana penyalahgunaan narkotika merupakan tindak pidana yang unik, seperti halnya tindak pidana perjudian. Keunikan dari tindak pidana ini terletak pada status kedudukan Penyalahguna Narkotika itu sendiri. Status Penyalahguna Narkotika itu apakah sebagai pelaku tindak pidana atau sebagai korban tindak pidana. Kebanyakan orang menganggap bahwa penyalahguna narkotika adalah pelaku sekaligus korban tindak pidana, namun sebenarnya apakah memang demikian? Status kedudukan yang demikian ini penting diketahui, dipahami karena akan lebih mudah menentukan kebijakan legislasi yang tepat apakah penyalahguna narkotika itu dapat dipertanggungjawabkan dalam hukum pidana atau tidak, atau sanksi apa yang tepat bagi mereka. Apabila ia berkedudukan sebagai pelaku tindak pidana maka ia dapat dipertanggungjawabkan dalam hukum pidana, sebaliknya apabila ia korban tindak pidana, maka ia tidak perlu dipertanggungjawabkan dalam hukum pidana.

Secara normatif, Pasal 1 angka 15 UndangUndang Narkotika memberikan konsep hukum bahwa Penyalahguna adalah orang yang menggunakan Narkotika tanpa hak atau melawan hukum. Selanjutnya Pasal 127 ayat (1) UndangUndang Narkotika menyatakan dengan tegas bahwa Setiap Penyalahguna:

a. Narkotika Golongan I bagi diri sendiri dipidana dengan pidana penjara paling lama 4 (empat) tahun; 
b. Narkotika Golongan II bagi diri sendiri dipidana dengan pidana penjara paling lama 2 (dua) tahun; dan

c. Narkotika Golongan III bagi diri sendiri dipidana dengan pidana penjara paling lama 1 (satu) tahun.

Berpijak dari konsep hukum penyalahguna sebagaimana Pasal 1 angka 15 tersebut secara $a$ contrario, berarti ada orang yang menggunakan narkotika tetapi tidak melawan hukum, misalnya untuk pengobatan sesuai dengan petunjuk dokter. Sementara orang yang menggunakan narkotika tanpa hak atau yang tidak beralasan menurut hukum disebut menggunakan narkotika yang melawan hukum, sehingga disebut penyalahguna. Menurut ketentuan Pasal 127 Undang-Undang Narkotika tersebut jelas bahwa penyalah guna narkotika golongan I, II dan III diancam dengan pidana, sehingga secara yuridis penyalahguna narkotika adalah pelaku tindak pidana. Namun apabila dikaji lebih jauh apakah memang setiap orang yang menggunakan narkotika tanpa hak atau melawan hukum itu merupakan penyalah guna narkotika yang dijatuhi pidana berdasarkan ketentuan Pasal 127 Undang-Undang Narkotika.

Sehubungan dengan persoalan dikotomis status penyalahguna antara pelaku dengan korban tersebut, muncul pertanyaan, apakah penyalahguna narkotika itu berstatus sebagai pelaku tindak pidana atau korban tindak pidana? Undang-undang Narkotika tidak memberikan penjelasan tentang hal ini. Pemahaman tentang hal ini perlu dicermati ketentuan Pasal 54 Undang-undang Narkotika yang menentukan bahwa pecandu Narkotika dan korban penyalahgunaan Narkotika wajib menjalani rehabilitasi medis dan rehabilitasi sosial. Selanjutnya penjelasan Pasal 54 Undang-undang Narkotika, menentukan bahwa korban penyalahgunaan narkotika adalah seseorang yang tidak sengaja menggunakan narkotika karena dibujuk, diperdaya, ditipu, dipaksa, dan/atau diancam untuk menggunakan Narkotika. Hal ini berarti bahwa korban penyalahgunaan narkotika itu adalah orang yang tanpa hak menggunakan narkotika dengan tidak sengaja, melainkan karena dibujuk, diperdaya, ditipu, dipaksa, dan/atau diancam untuk menggunakan Narkotika. Orang yang tanpa hak menggunakan narkotika adalah penyalahguna narkotika. Jadi sebagian penyalahguna narkotika adalah korban penyalahgunaan narkotika. Berpijak dari penjelasan Pasal 54 Undang-undang Narkotika, secara a contrario dapat dikatakan bahwa orang yang dengan sengaja menggunakan narkotika secara tanpa hak adalah pelaku penyalahguna narkotika. Dengan demikian melalui pendekatan normatif, dapat dikatakan bahwa penyalahguna narkotika itu ada yang berkedudukan sebagai pelaku tindak pidana dan ada yang berkedudukan sebagai korban tindak pidana, bukan berkedudukan sebagai pelaku tindak pidana sekaligus sebagai korban tindak pidana.

Secara sosio-viktimologis, penyalahguna narkotika adalah pelaku sekaligus sebagai korban. Penyalahguna narkotika dikatakan sebagai pelaku tindak pidana karena seseorang yang menggunakan narkotika tanpa hak atau melawan hukum merupakan perbuatan yang bertentangan dengan nilai-nilai sosial dan sekaligus penyalahguna narkotika sebagai korban tindak pidana atas perbuatannya sendiri, karena dampak penyalahgunaan narkotika itu menimpa dirinya sendiri, yaitu merusak kesehatan dan bahkan dapat menimbulkan kematian. Sebenarnya korban dari penyalahgunaan narkotika itu tidak hanya diri sendiri melainkan juga keluarga dari penyalahguna sebagai pelaku tindak pidana itu.

Secara filosofis teologis,pada hakikatnya, pelaku kejahatan adalah orang yang tidak mampu berbuat adil, ia tidak mampu berbuat adil terhadap diri sendiri, ia tidak mampu berbuat adil terhadap masyarakat dan lingkungan, dan ia tidak mampu berbuat adil terhadap Tuhan yang menciptakannya. Orang yang melakukan kejahatan adalah juga 
orang yang tidak mampu mengendalikan diri, sehingga dapat dikatakan bahwa penyalahguna narkotika adalah orang yang tidak mampu mengendalikan diri untuk tidak menggunakan narkotika tanpa hak atau melawan hukum, sehingga ia tidak mampu berbuat adil terhadap diri sendiri, lingkungan masyarakat dan Tuhan yang menciptakannya. Perspektif ini, dapat dikatakan bahwa penyalahguna narkotika berkedudukan sebagai pelaku tindak pidana, karena perbuatan menyalahgunakan narkotika merupakan perbuatan yang melanggar nilai-nilai dan rasa keadilan yang ada dalam masyarakat. Demikian pula, penyalahguna berkedudukan sebagai korban tindak pidana, karena perbuatan menyalahgunakan narkotika merupakan perbuatan yang melanggar hak-hak dan keadilan terhadap diri sendiri.

\section{Sanksi Pidana atau Sanksi Tindakan}

Sanksi apa yang tepat bagi penyalahguna narkotika, sanksi pidana atau sanksi tindakan? Penjatuhan atau pemberian sanksi terhadap penyalahguna narkotika harus didasarkan pada tujuan dari penjatuhan atau pemberian sanksi tersebut terhadap penyalahguna narkotika. Agar dapat lebih memahami persoalan tersebut, perlu dipertimbangkan tentang filsafat atau ide dasar yang mendasari sanksi pidana dan sanksi tindakan tersebut.

Dua jenis sanksi ini, sanksi pidana dan sanksi tindakan ini sering dibedakan secara dikotomis dalam pembicaran masalah sanksi. Sanksi pidana merupakan jenis sanksi yang dikembangkan aliran klasik dengan filsafat indeterminis yang mendasarinya. Sedangkan sanksi tindakan merupakan jenis sanksi yang dikembangkan aliran modern dengan filsafat determinis yang mendasarinya.

Filsafat indeterminisme sebagai sumber sanksi pidana memiliki asumsi dasar bahwa manusia mempunyai kehendak yang bebas (free will), termasuk ketika ia melakukan kejahatan. Sebagai konsekuensi pilihan bebasnya maka setiap sanksi harus diarahkan pada pencelaan moral dan pengenaan penderitaan bagi pelaku, yaitu dengan pidana. Sedangkan filsafat determinisme sebagai sumber sanksi tindakan bertolak dari asumsi bahwa keadaan hidup dan perilaku manusia, baik sebagai perorangan maupun sebagai kelompok masyarakat ditentukan oleh faktor-faktor fisik, geografis, biologis, psikologis, sosiologis, ekonomis dan keagamaan yang ada. Perilaku jahat seseorang ataupun masyarakat ditentukan oleh berbagai faktor dan oleh karenanya setiap sanksi yang dijatuhkan hanya dapat dibenarkan dengan maksud merehabilitasi pelaku. Oleh karena itu aliran hukum pidana modern ini mencari alternatif-alternatif sanksi di luar sanksi pidana yang telah ada. Sanksi yang dimaksud adalah sanksi tindakan atau maatregel atau treatment.

Sanksi tindakan lebih bersifat antisipatif terhadap pelaku perbuatan, sedangkan sanksi pidana sesungguhnya lebih bersifat reaktif terhadap suatu perbuatan. Jika sanksi pidana tertuju pada perbuatan salah seseorang lewat pengenaan penderitaan agar yang bersangkutan menjadi jera, maka sanksi tindakan terarah pada upaya memberi pertolongan agar dia berubah (M. Sholehuddin, 2003, 32). Lebih tegas Masruchin Ruba'i (1994, 4) menyatakan: Secara teoritis perbedaan antara pidana dan tindakan didasarkan pada tujuannya. Pidana bertujuan memberikan penderitaan sebagai pembalasan kepada orang yang melakukan tindak pidana. Sedangkan tindakan bertujuan untuk mendidik orang yang melakukan tindak pidana atau bertujuan melindungi masyarakat terhadap bahaya yang mungkin timbul akibat perbuatan orang tertentu.

Oleh karena itu, berdasarkan tujuannya, sanksi pidana dan sanksi tindakan bertolak dari ide dasar yang berbeda. Sanksi pidana bertujuan memberi penderitaan kepada pelanggar agar merasakan akibat perbuatannya. Selain ditujukan pada pengenaan penderitaan terhadap pelaku, sanksi pidana juga merupakan bentuk pernyataan 
pencelaan terhadap perbuatan si pelaku (M. Sholehuddin, 2003, 32, 33). Sedangkan sanksi tindakan tujuannya lebih bersifat mendidik (E. Utrecht, 1987, 360). Dengan demikian, perbedaan prinsip antara sanksi pidana dengan sanksi tindakan terletak pada ada tidaknya unsur pencelaan, bukan pada ada tidaknya unsur penderitaan. Namun menurut Roeslan Saleh, dalam banyak hal, batas antara sanksi pidana dengan sanksi tindakan secara teoritis sukar ditentukan secara pasti, oleh karena sanksi pidana sendiripun dalam banyak hal juga mengandung pikiran-pikiran melindungi dan memperbaiki (Roeslan Saleh, 1987, 47).

Berdasarkan ide dasar dan tujuan dari sanksi pidana dan sanksi tindakan tersebut, sanksi mana yang lebih tepat bagi penyalahguna narkotika? Sanksi pidana atau sanksi tindakan? Dilihat dari ide dasar yang mendasari perbuatan penyalahguna narkotika menurut hemat saya, pada umumnya didasari oleh kehendak dari penyalahguna yang tidak bebas. Ia banyak dipengaruhi oleh cara berpikir yang salah, karena teman pergaulan dan atau karena lingkungan sosial yang tidak baik. Sedangkan dilihat dari segi tujuan sanksi pidana atau sanksi tindakan menurut hemat saya, lebih cenderung pada tujuan sanksi tindakan, yaitu tujuan yang bersifat preventif, edukatif dan antisipatif. Apakah kita rela penyalahguna yang keadaannya sudah demikian parah masih harus dijatuhi sanksi pidana dengan segala dampak negatifnya. Mereka yang menyalahgunakan narkotika dan kemudian tersangkut masalah hukum banyak yang dikirim ke Lembaga Pemasyarakatan sebagai salah satu bentuk pembinaan. Tentu dengan harapan agar penyalahguna ini dapat pulih menjadi orang yang baik, berguna bagi bangsa dan negara. Namun, yang terjadi seperti kita tahu bersama kondisi tersebut tidak kemudian dapat meyelesaikan masalah bahkan cenderung menciptakan masalah baru. Para penyalahguna yang awalnya hanya coba-coba ketika berada di Lembaga Pemasyarakatan mereka berinteraksi dengan penyalahguna yang sudah senior dan bahkan para bandar yang pada akhirnya mereka ini ketika keluar dari penjara menjadi lebih "pintar" dalam penyalahgunaan narkotika dan bahkan tidak jarang menjadi pengedar baru. Dengan demikian, merehabilitasi penyalahguna narkotika lebih banyak memberi dampak positif di antaranya si penyalahguna narkotika keluar dari masalah ketergantungan narkotika dan diharapkan ketika pulih dapat kembali ke masyarakat dan bersosialisasi kembali dengan masyarakat seperti sediakala.

Sesuai dengan sanksi tindakan ini adalah pendekatan Restorative Justice yang merupakan salah satu upaya pendekatan penyelesaian perkara pidana yang lebih menekankan pemulihan kembali semaksimal mungkin keadaan korban ke keadaan semula dengan melibatkan berbagai pihak. Pendekatan ini diperlukan karena dalam berbagai perkara, sanksi pidana penjara yang di tujukan untuk mendapatkan rasa efek jera kepada pelaku tidak terlalu memberi manfaat positif untuk merubah si pelaku agar jera tidak mengulangi perbuatannya lagi dan juga tidak menjamin akan adanya perbaikan. Pendekatan Restorative Justice ini dapat dianggap lebih efektif dari pada memberikan sanksi berupa pidana penjara.

\section{Reorientasi Kebijakan Sistem Sanksi Bagi Penyalahguna Narkotika}

Pasal 1 angka 15 menentukan Penyalahguna adalah orang yang menggunakan Narkotika tanpa hak atau melawan hukum. Selain istilah penyalahguna narkotika, Undang-Undang Nomor 35 Tahun 2009 Tentang Narkotika ini juga memberikan pengertian pecandu narkotika dan korban penyalahgunaan narkotika. Rumusan Pasal 1 angka 13 Undang-Undang Narkotika menentukan bahwa Pecandu Narkotika adalah orang yang menggunakan atau menyalahgunakan narkotika dan dalam keadaan ketergantungan pada Narkotika, baik secara fisik maupun psikis. Sedang- 
kan pengertian korban penyalahgunaan narkotika dapat dilihat dalam Penjelasan Pasal 54 Undangundang Narkotika yang menyatakan "korban penyalahgunaan Narkotika" adalah seseorang yang tidak sengaja menggunakan narkotika karena dibujuk, diperdaya, ditipu, dipaksa, dan/atau diancam untuk menggunakan Narkotika.

Berbagai ketentuan dalam Undang-Undang Nomor 35 Tahun 2009 Tentang Narkotika menggunakan rumusan tentang penyalahgunaan narkotika dan pengedaran narkotika, misal penyidikan, penuntutan, dan pemeriksaan di sidang pengadilan terhadap penyalahgunaan narkotika dan pengedaran narkotika (Pasal 73), kewenangan penyidik Polri, dan penyidik BNN terhadap penyalahgunaan dan pengedaran narkotika (Pasal 81), seperti pemeriksaan, penggeledahan, penyitaan, penangkapan, penahanan terhadap penyalahgunaan narkotika dan pengedaran narkotika. Berbagai rumusan ketentuan tersebut, menunjukkan bahwa Undang-Udang Narkotika ini membedakan antara tindak pidana penyalahgunaan (termasukpecandu dan korban) narkotika dan tindak pidana pengedaran (termasuk penanam, produsen, penyimpan, pengangkut) narkotika. Namun tulisan ini difokuskan saja pada persoalan yang berhubungan dengan penyalahguna narkotika.

Secara normatif, penyalahgunaan narkotika merupakan salah satu jenis tindak pidana yang diatur dalam Undang-Undang Narkotika. Hal ini berarti orang yang menyalahgunakan narkotika itu adalah pelaku tindak pidana narkotika, yang secara tegas Pasal 127 Undang-undang tersebut menentukan bahwa

(1) Setiap Penyalah Guna:

a. Narkotika Golongan I bagi diri sendiri dipidana dengan pidana penjara paling lama 4 (empat) tahun;

b. Narkotika Golongan II bagi diri sendiri dipidana dengan pidana penjara paling lama 2 (dua) tahun; dan c. Narkotika Golongan III bagi diri sendiri dipidana dengan pidana penjara paling lama 1 (satu) tahun.

(2) Dalam memutus perkara sebagaimana dimaksud pada ayat (1), hakim wajib memperhatikan ketentuan sebagaimana dimaksud dalam Pasal 54, Pasal 55, dan Pasal 103.

(3) Dalam hal Penyalah Guna sebagaimana dimaksud pada ayat (1) dapat dibuktikan atau terbukti sebagai korban penyalahgunaan Narkotika, Penyalah Guna tersebut wajib menjalani rehabilitasi medis dan rehabilitasi sosial.

Pasal 54 menentukan bahwa: Pecandu Narkotika dan korban penyalahgunaan Narkotika wajib menjalani rehabilitasi medis dan rehabilitasi sosial. Kemudian Pasal 55 menentukan bahwa

(1) Orang tua atau wali dari Pecandu Narkotika yang belum cukup umur wajib melaporkan kepada pusat kesehatan masyarakat, rumah sakit, dan/atau lembaga rehabilitasi medis dan rehabilitasi sosial yang ditunjuk oleh Pemerintah untuk mendapatkan pengobatan dan/atau perawatan melalui rehabilitasi medis dan rehabilitasi sosial.

(2) Pecandu Narkotika yang sudah cukup umur wajib melaporkan diri atau dilaporkan oleh keluarganya kepada pusat kesehatan masyarakat, rumah sakit, dan/atau lembaga rehabilitasi medis dan rehabilitasi sosial yang ditunjuk oleh Pemerintah untuk mendapatkan pengobatan dan/atau perawatan melalui rehabilitasi medis dan rehabilitasi sosial.

(3) Ketentuan mengenai pelaksanaan wajib lapor sebagaimana dimaksud pada ayat (1) dan ayat (2) diatur dengan Peraturan Pemerintah.

Sedangkan Pasal 103 menentukan bahwa

(1) Hakim yang memeriksa perkara Pecandu Narkotika dapat:

a. memutus untuk memerintahkan yang bersangkutan menjalani pengobatan dan/ 
atau perawatan melalui rehabilitasi jika Pecandu Narkotika tersebut terbukti bersalah melakukan tindak pidana Narkotika; atau

b. menetapkan untuk memerintahkan yang bersangkutan menjalani pengobatan dan/ atau perawatan melalui rehabilitasi jika Pecandu Narkotika tersebut tidak terbukti bersalah melakukan tindak pidana Narkotika.

(2) Masa menjalani pengobatan dan/atau perawatan bagi Pecandu Narkotika sebagaimana dimaksud pada ayat (1) huruf a diperhitungkan sebagai masa menjalani hukuman.

Kebijakan legislasi sebagaimana terdapat dalam ketentuan pidana sebagaimana diatur dalam Pasal 127 ayat (1) jo Pasal 54, 55 dan 103 ayat (1) huruf a, menurut hemat saya, merupakan kebijakan sistem dua jalur (double track system). Hal ini berarti bahwa dalam kebijakan aplikasi, apabila penyalahguna narkotika terbukti dengan sengaja menggunakan narkotika secara melawan hukum untuk diri sendiri, bukan pengedar narkotika, hakim menjatuhkan sanksi pidana sebagaimana yang diatur dalam Pasal 127 (1) dan sekaligus hakim memerintahkan penyalahguna narkotika yang bersangkutan untuk menjalani pengobatan dan/atau perawatan melalui rehabilitasi medis dan rehabilitasi sosial sebagaimana dimaksud Pasal 103 ayat (1) huruf a dan Pasal 54.

Selanjutnya Pasal 103 ayat (2) menentukan bahwa masa menjalani pengobatan dan/atau perawatan bagi Pecandu Narkotika sebagaimana dimaksud pada ayat (1) huruf a diperhitungkan sebagai masa menjalani hukuman. Menurut hemat saya, ketentuan ini bukan depenalisasi, karena apabila masa pidana/hukuman yang dijatuhkan hakim lebih lama dari masa menjalani rehabilitasi medis dan rehabilitasi sosial (karena sudah sembuh), maka sisa masa pidana/hukuman yang telah dijatuhkan hakim harus dijalani penyalahguna narkotika tersebut di Lembaga Pemasyarakatan (LP). Pada hal dampak negatif kehidupan di LP demikian parah, yang dikuatirkan menjadi lebih jelek. Oleh karena itu menurut hemat saya, ketentuan Pasal 127 dan Pasal 103 perlu didepenalisasi ini, dengan rumusan:

(1) Hakim yang memeriksa Penyalahguna Narkotika memutus sanksi tindakan bagi penyalahguna narkotika yang terbukti bersalah melakukan tindak pidana penyalahgunaan narkotika.

(2) Setiap Penyalah Guna Narkotika untuk diri sendiri yang tidak terbukti sebagai pengedar narkotika wajib menjalani Rehabilitasi medis dan rehabilitasi sosial.

Selanjutnya ketentuan Pasal 128 ayat (2) menentukan bahwa Pecandu Narkotika yang belum cukup umur dan telah dilaporkan oleh orang tua atau walinya sebagaimana dimaksud dalam Pasal 55 ayat (1) tidak dituntut pidana. Kemudian ayat (3) Pasal tersebut menentukan bahwa Pecandu Narkotika yang telah cukup umur sebagaimana dimaksud dalam Pasal 55 ayat (2) yang sedang menjalani rehabilitasi medis 2 (dua) kali masa perawatan dokter di rumah sakit dan/atau lembaga rehabilitasi medis yang ditunjuk oleh pemerintah tidak dituntut pidana.

Ketentuan Pasal 128 ayat (2) dan ayat (3)jo Pasal 55 ayat (1) dan ayat (2) menurut hemat saya, merupakan alasan penghapus penuntutan khusus, karena kalau ketentuan Pasal 55 ayat (1) dan ayat (2) tidak dipenuhi maka Pecandu Narkotika tersebut dapat dituntut pidana berdasarkan Pasal 127 ayat (1). Namun, apabila diperhatikan ketentuan tersebut dapat juga dikatakan sebagai depenalisasi sukarela atau depenalisasi bersyarat, karena apabila syarat yang ditentukan dalam Pasal 55 ayat (1) dan ayat ((2) tidak dipenuhi maka bukan depenalisasi, karena Pecandu narkotika tersebut dapat dituntut pidana berdasarkan ketentuan Pasal 127 ayat (1). 


\section{Penutup}

Penyalahgunaan narkotika merupakan tindak pidana kejahatan yang diancam dengan pidana. Penyalah guna narkotika bisa berkedudukan sebagai pelaku tindak pidana dan juga bisa berkedudukan sebagai korban tindak pidana. Penyalahguna Narkotika berkedudukan sebagai pelaku tindak pidana jika dengan sengaja tanpa hak atau melawan hukum menggunakan narkotika untuk diri sendiri, dan Penyalahguna Narkotika berkedudukan sebagai korban tindak pidana penyalahgunaan narkotika jika tidak sengaja tanpa hak atau melawan hukum (karena dibujuk, diperdaya, ditipu, dipaksa, dan/atau diancam) menggunakan narkotika. Adapun sanksi yang sesuai dengan ide dasar dan tujuan diberikannya sanksi bagi penyalahguna narkotika adalah sanksi tindakan, maatregel, antara lain rehabilitasi medis dan rehabilitasi sosial.

Kebijakan legislasi yang terdapat dalam Pasal 127 jo Pasal 103 ayat (1) Undang-undang Narkotika merupakan sistem dua jalur (double track system). Ketentuan Pasal 103 ayat (2) Undang-undang Narkotika ini bukan depenalisasi, karena apabila masa pidana/hukuman yang dijatuhkan hakim lebih lama dari masa menjalani rehabilitasi medis dan rehabilitasi sosial (karena sudah sembuh), maka sisa masa pidana/hukuman yang telah dijatuhkan hakim harus dijalani penyalahguna narkotika tersebut di Lembaga Pemasyarakatan (LP). Adapun Ketentuan Pasal 128 ayat (2) dan ayat (3) jo Pasal 55 ayat (1) dan ayat (2) merupakan alasan penghapus penuntutan khusus atau depenalisasi bersyarat.

Sesuai dengan ide dasar dan tujuan diberikannya sanksi pada penyalahguna narkotika ini maka ketentuan sistem sanksi bagi penyalahguna narkotika yang diatur dalam Undang-undang Narkotika ini perlu didepenalisasikan.

\section{DAFTAR PUSTAKA}

Hamel, Van, dalam P.A.F. Lamintang, 1990. Dasar-dasar Hukum Pidana Indonesia, Sinar Baru, Bandung.

Ruba'i, Masruchin, 1994. Mengenal Pidana dan Pemidaaandi Indonesia, Penerbit IKIP Malang, Malang.

Saleh, Roeslan, 1987. Stelsel Pidana Indonesia, Penerbit Aksara Baru, Jakarta.

Sholehuddin, M., 2003. Sistem sanksi Dalam Hukum Pidana, Ide Dasar Double Track System \& Implementasinya, PT. RajaGrafindo Persada, Jakarta

Sudarto, 1987. Hukum Pidana 1, Badan Penyediaan Bahan Kuliah, Fakultas Hukum Universitas Diponegoro, Semarang.

Utrecht, E., 1987. Rangkaian Sari Kuliah Hukum Pidana II, PenerbitPustaka Tinta Mas, Surabaya.

Badan Narkotika Nasional, Laporan Akhir SurveiNasional Perkembangan Penyalahguna Narkoba Tahun Anggaran 2014, Januari 2015.

Slamet, Dampak Sosial Penyalahgunaan Narkotika, Portal Resmi Pemerintah Kota Depok, http:// www.depok.go.id, up load 30 September 2015, down load, 7 Agustus 2017. 